\title{
Familial Summer-type Hypersensitivity Pneumonitis: A Review of 25 Families and 50 Cases in Japan
}

\author{
Nobuhiro Asai ${ }^{1}$, Norihiro Kaneko ${ }^{1}$, Yoshihiro Ohkuni ${ }^{1}$, \\ Masahiro Aoshima $^{1}$ and Yasutaka Kawamura ${ }^{2}$
}

\begin{abstract}
Summer-type hypersensitivity pneumonitis (SHP) is the most common form of pneumonitis in Japan; it accounts for $74 \%$ of all cases. It has been reported that 19.5-23.8\% of SHP cases occur in families who live in the same house. We present our SHP cases and review 50 familial cases in 23 families that were reported in Japan (including our own) and 48 cases that were previously described in 22 articles published between January 1982 and October 2011. To the best of the authors' knowledge, this is the first review article in English to document the familial occurrence of SHP in Japan.
\end{abstract}

Key words: summer-type hypersensitivity pneumonitis, Trichosporon, HLA-DQ

(Intern Med 55: 279-283, 2016)

(DOI: 10.2169/internalmedicine.55.5121)

Introduction

Hypersensitivity pneumonitis (HP) is an immunologically induced lung disease caused by repeated inhalation of a variety of causative antigens (1). A previous epidemiologic study of 621 HP cases in Japan demonstrated that summertype hypersensitivity pneumonitis (SHP) is the most common form of HP in Japan; it accounts for $74 \%$ of all cases (2). SHP most often occurs in the western part of Japan, where the summer weather typically consists of high temperatures and high humidity. It has been reported that 19.5-23.8 \% of SHP cases occur in families who live in the same house $(2,3)$. The familial occurrence of SHP is considered to be related, not only to environmental factors, but also to hereditary factors such as the presence of the human leukocyte antigen (HLA) $(4,5)$. In 1982, Kohaku et al. published the first report of familial SHP cases; since then, a total of 50 Japanese patients in 23 families with familial SHP have been reported, including our cases which we report here. In this article, we present our cases and review all of the previously reported cases of familial SHP in Japan, published between January 1982 and October 2011 (5-26). To the best of the authors' knowledge, this is the first review article in English, to document the familial occurrence of
SHP in Japan.

\section{Case Reports}

\section{Patient 1}

Patient \#1 was a 19-year-old man who had never smoked and had no history of allergic diseases. Visiting a local hospital, he complained of exertional dyspnea and a dry cough lasting for one month from August 2011. He was admitted to the hospital and diagnosed with atypical pneumonia by laboratory findings and chest radiography. Intravenous antibiotics and steroid pulse therapy were initiated and his symptoms rapidly improved. He was discharged after 14 days of hospitalization. However, he experienced a recurrence 2 days after discharge and was referred to our hospital.

\section{Patient 2}

Patient \#2 was the mother of Patient \#1. She was 49 years of age and had never smoked. She presented a fever and general fatigue of one month in duration from August 2011. She came to take her son to our hospital, and then consulted us. In both the mother and the son, a mild elevation of inflammatory reactions such as C-reactive protein

${ }^{1}$ Department of Pulmonology, Kameda Medical Center, Japan and ${ }^{2}$ Department of Radiology, Kameda Medical Center, Japan Received for publication February 9, 2015; Accepted for publication April 23, 2015

Correspondence to Dr. Nobuhiro Asai, nobuhiro0204@hotmail.com 
Table 1. Patients' Characteristics.

\begin{tabular}{|c|c|c|}
\hline \multirow[t]{2}{*}{ Characteristics } & \multicolumn{2}{|c|}{ Patients } \\
\hline & \multicolumn{2}{|c|}{ No $(\%)$} \\
\hline Mean age, years (range) & \multicolumn{2}{|c|}{$33.5(2-74)$} \\
\hline \multicolumn{3}{|l|}{ Sex } \\
\hline Male & \multicolumn{2}{|c|}{$22(44)$} \\
\hline Female & \multicolumn{2}{|l|}{$28(56)$} \\
\hline \multirow[t]{4}{*}{ Smoking history $(\mathrm{n}=31) \dagger$} & Never & $20(65)$ \\
\hline & Ex-smoker & $7(23)$ \\
\hline & Current smoke & $4(13)$ \\
\hline & N.D. & 19 \\
\hline \multirow{8}{*}{ Month of onset $(n=49) \dagger$} & May & $2(4)$ \\
\hline & June & $2(4)$ \\
\hline & July & $8(16)$ \\
\hline & August & $26(53)$ \\
\hline & September & $7(14)$ \\
\hline & October & $3(6)$ \\
\hline & November & $1(2)$ \\
\hline & N.D. & 1 \\
\hline \multirow[t]{5}{*}{ Symptoms on initial visit $(n=48) \dagger$} & Cough & $43(90)$ \\
\hline & Sputum & $11(23)$ \\
\hline & Fever & $40(83)$ \\
\hline & Dyspnea & $38(79)$ \\
\hline & N.D. & 2 \\
\hline \multirow[t]{2}{*}{ Blood relation of the families $(n=23)$} & Blood relation & $15(65)$ \\
\hline & Not blood relation & $8(35)$ \\
\hline \multirow[t]{2}{*}{ Treatment } & Elimination of the antige & $25(50)$ \\
\hline & Steroid therapy & $25(50)$ \\
\hline $\begin{array}{l}\text { Mean duration from living to occurrence of } \\
\text { HP (Months, range) }\end{array}$ & \multicolumn{2}{|c|}{$15.0(0.5-396)$} \\
\hline Mean house age (Years, range) & \multicolumn{2}{|c|}{$20.4(14.0-33.0)$} \\
\hline \multirow[t]{3}{*}{ Movement $(\mathrm{n}=47) \dagger$} & Needed & $19(40)$ \\
\hline & Not needed & $28(60)$ \\
\hline & N.D. & 3 \\
\hline
\end{tabular}

*N.D. means not described in the paper.

$\dagger$ The cases not described in the paper, were excluded in the table.

(CRP), erythrocyte sedimentation rate (ESR) were found. High resolution chest computed tomography showed diffuse centrilobular nodules. A bronchoalveolar lavage fluid (BALF) analysis revealed a high proportion of lymphocytes with a decreased CD4/CD8 ratio and transbronchial lung biopsy specimens showed alveolitis associated with granuloma. They were diagnosed with SHP on the basis of the detection of anti-Trichosporon asahii antibodies in both the BALF and serum.

The condition of both patients improved within one week after admission by the avoidance of antigens, without any medication. Both of them were positive for a provocation test, which consisted of returning home. This resulted in them moving to another house. There was no recurrence during the 6-month observation period.

Their 50-year old wooden house was found to be damp and dusty, especially in the room of Patient \#1. Trichosporon asahii, an arthrospore-forming yeast, which was isolated in their house environment, was the likely causative agent (27). They had lived in the house for 18 years.

We reviewed 50 familial SHP cases of 23 families that have been reported in Japan, including our own in this study and 48 cases that were detailed in 22 previously published articles. The results are shown in Table 1.
The patients with familial SHP included 22 males and 28 females, with a mean age $( \pm \mathrm{SD})$ of $33.5 \pm 18.0$ years. Eighteen $(36 \%)$ patients were younger than the age of 20 years. All of the families lived in traditional Japanese wooden houses which were damp. Forty-one of the 49 cases (84\%) occurred between July and September in summer in Japan (Table 1). All of the familial occurrence of SHP occurred within 2 months of the first case of HP within the family. Eight patients of the 23 families (35\%), were not blood relations of another patient in the same family. In terms of host and genetic factors, there is a relatively high incidence of HP in housewives and nonsmokers. Fifty-six percent of SHP patients were females and $44 \%$ were males. Four of the patients $(13 \%)$ in our study were current smokers. In terms of treatment, 25 patients $(50 \%)$ received steroid therapy, while the remaining $25(50 \%)$ improved without any medication. Nineteen $(40 \%)$ patients needed to move to another house.

\section{Discussion}

It is supposed that less frequent smoking and a longer duration of exposure to antigens would be related to HP occurring more frequently in women than in men (28). Furthermore, it has already been reported that cigarette smoking has a suppressive effect in patients susceptible to 
Table 2. Laboratory Data and Pulmonary Function Test.

\begin{tabular}{|c|c|c|c|c|}
\hline & $\begin{array}{c}\text { Elder brother } \\
\text { (Patient \#1) }\end{array}$ & $\begin{array}{c}\text { Mother } \\
\text { (Patient \#2) }\end{array}$ & Father & Young brother \\
\hline Age & 19 & 49 & 52 & 14 \\
\hline Sex & Male & Female & Male & Male \\
\hline \multicolumn{5}{|l|}{ Hematology } \\
\hline WBC $\left(/ \mathrm{mm}^{3}\right)$ & 5,300 & 8,400 & & \\
\hline Neu $(\%)$ & 56 & 91 & & \\
\hline Lym (\%) & 31 & 8 & & \\
\hline Eos $(\%)$ & 6 & 0 & & \\
\hline \multicolumn{5}{|l|}{ Biochestry } \\
\hline LDH (IU/L) & 333 & 279 & & \\
\hline $\operatorname{ESR}(\mathrm{mm} / 1 \mathrm{hr})$ & 25 & 32 & & \\
\hline \multicolumn{5}{|l|}{ Serology } \\
\hline $\mathrm{CRP}(\mathrm{mg} / \mathrm{dL})$ & 1.33 & 0.95 & & \\
\hline KL-6 (IU/mL) & 1,130 & 2,150 & & \\
\hline SP-D (ng/mL) & 257 & 144 & & \\
\hline $\begin{array}{l}\text { Anti-Trichosporon } \\
\text { asahii antibody }\end{array}$ & positive & positive & positive & negative \\
\hline \multicolumn{5}{|l|}{ Blood gas analysis } \\
\hline $\mathrm{PaO}_{2}(\mathrm{mmHg})$ & 67.7 & 74.5 & & \\
\hline $\mathrm{PaCO}_{2}(\mathrm{mmHg})$ & 37.2 & 36.1 & & \\
\hline \multicolumn{5}{|l|}{$\begin{array}{l}\text { Pulmonary function } \\
\text { test }\end{array}$} \\
\hline $\mathrm{VC}(\mathrm{L})$ & 2.81 & 2.61 & & \\
\hline$\% \mathrm{VC}(\%)$ & 65.8 & 101.2 & & \\
\hline $\mathrm{FEV}_{1.0}(\mathrm{~L})$ & 2.07 & 2.13 & & \\
\hline $\mathrm{FEV}_{1.0 \%}(\%)$ & 50.0 & 95.9 & & \\
\hline$\% \operatorname{DLCO}(\%)$ & 38.6 & 70.7 & & \\
\hline \multicolumn{5}{|l|}{ BALF analysis } \\
\hline Total cell count $(/ \mu \mathrm{L})$ & 825 & 875 & & \\
\hline Neu $(\%)$ & 7 & 5 & & \\
\hline Lym (\%) & 74 & 62 & & \\
\hline Eos $(\%)$ & 5 & 6 & & \\
\hline $\mathrm{M} \varphi(\%)$ & 14 & 27 & & \\
\hline $\mathrm{CD} 4 / 8$ ratio & 0.37 & 0.1 & & \\
\hline \multicolumn{5}{|l|}{ HLA type } \\
\hline A & A 24 & A 24 & $\mathrm{~A} 2, \mathrm{~A} 24$ & A24 \\
\hline B & B48, B52 & B48, B51 & B52, B54 & B48, B54 \\
\hline DR & DR9, DR15 & DR9, DR14 & DR15 & DR9, DR15 \\
\hline $\begin{array}{l}\text { WBC: white blood } \\
\text { dehydrogenase, ESR: } \\
\text { Lungen-6, SP-D: surf } \\
\text { second, DLCO: diffusi } \\
\text { macrophage, HLA: hu }\end{array}$ & $\begin{array}{l}\text { Neu: neutoc } \\
\text { rocyte sedimen } \\
\text { t protein } \mathrm{D}, \mathrm{V} \\
\text { apacity for car } \\
\text { leukocyte antig }\end{array}$ & $\begin{array}{l}\text { m: lymphoc } \\
\text { rate, CRP: C- } \\
\text { capacity, FE } \\
\text { noxide, BAL }\end{array}$ & $\begin{array}{l}\text { Eos: eosin } \\
\text { ve protein, } \\
\text { forced expi } \\
\text { onchoalveol }\end{array}$ & $\begin{array}{l}\text { 1, LDH: lactate } \\
\text { 6: Krebs von den } \\
\text { y volume in one } \\
\text { avage fluid, } \mathrm{M} \varphi \text { : }\end{array}$ \\
\hline
\end{tabular}

HP $(29,30)$. The prevalence of anti-T. asahii antibody was significantly lower in smoker $(29,31)$. It is presumed that cigarette smoking stimulates the production of alveolar macrophages and accelerates the clearance of the lungs. In addition, some physicians demonstrated that the elevation of estrogen could correlate with lung injury and pulmonary fibrosis $(32,33)$. This suggests that gender plays an important role in the occurrence of HP.

Due to the close relationship between the immune system and HLA, some physicians have reported the possibility of a genetic predisposition linked to this system.

Ando et al. documented the increased frequency of HLADQw3 in Japanese patients with T. asahii-induced SHP (2). The occurrence of SHP has also been reported to be related to HLA-A2 and DR9 (3). Table 2 shows the results of the laboratory data, pulmonary function test and HLA type in the family of our cases. In our cases, both of the HP patients had HLA-DR9. While the father of Patient \#1 had HLA-A2, and did not show anti-T. asahii antibody-positive HP. This suggests that the occurrence of HP may not only be related to the environmental factors such as the duration of inhalational exposure and climate but also to the host's hereditary susceptibility to the antigens.

As for home environmental factors, the old wooden houses were found to be damp, dusty and poorly ventilated, especially in the room of Patient \#1. T. asahii was also isolated in their house. The arthrospore-forming yeast, was the likely causative agent (27). They had lived in a moldy house for 13 years. Both Patients \#1 and \#2 often stayed in the room of Patient \#1. In contrast, the younger brother and father did not visit the room although they were positive for anti-T. asahii antibodies. The duration of inhalational expo- 
sure could affect sensitization to Trichosporon antigens and the occurrence of SHP.

In terms of clinical symptoms, about $90 \%$ of the SHP patients presented with cough, fever and dyspnea. All of the patients' houses were wooden and the mean house age was 20.4 years. Ando et al. documented the clinical symptoms and the length of time that SHP patients had resided in their homes. Coughing was the most common symptom, and fever was seen in about $90 \%$ of patients. Exertional dyspnea was also seen in approximately $80 \%$ of patients. The patients' houses were $89.5 \%$ wooden and $10.5 \%$ non-wooden, with a mean house age of 20.5 years for wooden houses and 12.3 years for non-wooden ones. Thus, there was no difference in the patient characteristics of the familial and nonfamilial cases of SHP (28).

In conclusion, familial SHP does sometimes occur. Clinicians must therefore consider the possible occurrence of familial SHP, even in cases where household members are not blood relations.

\section{The authors state that they have no Conflict of Interest (COI).}

\section{Acknowledgement}

We are grateful for the diligent and thorough critical reading of our manuscript by Mr. John Wocher, Executive Vice President and Director, International Affairs/International Patient Services, Kameda Medical Center (Japan).

\section{References}

1. Fink JN. Hypersensitivity pneumonitis. J Allergy Clin Immunol 74: 1-10, 1984.

2. Ando M, Arima K, Yoneda R, Tamura M. Japanese summer-type hypersensitivity pneumonitis. Geographic distribution, home environment, and clinical characteristics of 621 cases. Am Rev Respir Dis 144: 765-769, 1991.

3. Makimoto N, Kajimoto K, Inoki A, et al. Familial outbreak with hypersensitivity pneumonitis. Nihon Naika Gakkai Zasshi (The Journal of the Japanese Society of Internal Medicine) 80: 11321133, 1991 (in Japanese).

4. Ando M, Hirayama K, Soda K, Okubo R, Araki S, Sasazuki T. HLA-DQw3 in Japanese summer-type hypersensitivity pneumonitis induced by Trichospron cutaneum. Am Rev Respir Dis 140: 948-950, 1989.

5. Amemiya Y, Shirai R, Ando S, et al. Familial summer-type hypersensitivity pneumonitis in a husband and wife. Arerugi (Japanese Journal of Allergology) 57: 1182-1187, 2008 (in Japanese).

6. Kodomari Y, Jyo T, Kuwabara M, et al. Familial case of summer type hypersensitivity pneumonitis. Hiroshima Kenritsu Byoin Ishi (Medical Journal of Hiroshima Prefectural Hospital) 14: 207-211, 1982 (in Japanese).

7. Yamamoto M, Kitaura S, Hanaki H, et al. Simultaneous occurrence of hypersensitivity pneumonitis (summer type) in a mother and a son. Nihon Kyobu Rinsho (The Japanese Journal of Chest Diseases) 43: 151-155, 1984 (in Japanese, Abstract in English).

8. Suda S, Suzuki R, Isono O, et al. A case report of hypersensitivity pneumonitis. Nihon Kyobu Rinsho (The Japanese Journal of Chest Diseases) 44: 475-479, 1985 (in Japanese, Abstract in English).

9. Nikaido Y, Miyazaki N, Kido M, et al. Summer-type hypersensitivity pneumonitis in 3 members of a family. Nihon Kyobu Rinsho (The Japanese Journal of Chest Diseases) 46: 876-883, 1987 (in Japanese, Abstract in English).
10. Fujino H, Tada T, Fujii Z, et al. A case of recurrent summer-type hypersensitivity pneumonitis associated with her spouse's occurrence. Yamaguchi Igaku 39: 121-125, 1990 (in Japanese).

11. Kawamura K, Iyori H, Seo K, et al. Familial summer-type hypersensitivity pneumonitis in a mother and her daughter. Shonika Sinryo (The Journal of Pediatric Practice) 55: 525-529, 1992 (in Japanese).

12. Aihara R, Shimakawa K, Yuasa Y, et al. Summer-type hypersensitivity pneumonitis in a mother and her daughter. Shonika Rinsho (Japanese Journal of Pediatrics) 47: 86-92, 1994 (in Japanese).

13. Kawayama T, Shigematsu H, Kawaguchi S, et al. Summer-type hypersensitivity pneumonitis in a family. Nihon Kyoubushikkan Gakkai Zasshi (The Japanese Journal of Thoracic Diseases) 34: 1401-1405, 1996 (in Japanese, Abstract in English).

14. Eda R, Miyahara N, Morimoto N, et al. Familial occurrence of summer-type hypersensitivity pneumonitis with positive antiTrichosporon cutaneum antibody. Arerugi no Rinsho (The Allergy in Practice) 17: 616-619, 1997 (in Japanese, Abstract in English).

15. Tahara M, Kawaguchi H, Kawamura $T$, et al. Familial summertype hypersensitivity pneumonitis in a mother and his son. Shonika (Pediatrics of Japan) 39: 969-975, 1998 (in Japanese).

16. Ubukata M, Takayanagi N, Matsushima H, et al. Familial summer-type hypersensitivity pneumonitis in a grandfather and his two-and-a-half-year-old grandson. Nihon Kokyuki Gakkai Zasshi 38: 923-927, 2000 (in Japanese, Abstract in English).

17. Fukabori T, Ueda M, Wakatsuki Y, et al. Family occurrence of summer-type hypersensitivity pneumonitis -case report-. Syakaihoken Kobe Chuobyoin Igaku Zasshi (Medical Journal of Shakaihoken Kobe Central Hospital) 7: 1-6, 2001 (in Japanese).

18. Kobayashi $Y$, Yasuba H, Kita $H$, et al. Simultaneous measurement of serum levels of KL-6 and SP-D in conjugal cases with hypersensitivity pneumonitis. Nihon Kyobu Rinsho (The Japanese Journal of Chest Diseases) 61: 330-337, 2002.

19. Mimura S, Kobayashi H, Kanoh S, et al. Summer-type hypersensitivity pneumonitis in monozygotic twins. Nihon Kokyuki Gakkai Zasshi 41: 133-137, 2003 (in Japanese, Abstract in English).

20. Tanaka Y, Shimizu S, Muroya K, et al. Familial case of summer type hypersensitivity pneumonitis induced by Trichosporon in an older brother and a younger sister. Shonika (Pediatrics of Japan) 45: 128-133, 2004 (in Japanese).

21. Sugiyama K, Mukae H, Ishii $H$, et al. Familial summer-type hypersensitivity pneumonitis--case report and review of literature. Nihon Kokyuki Gakkai Zasshi 43: 683-688, 2005 (in Japanese, Abstract in English).

22. Tanaka N, Taooka Y, Fujitaka K, et al. Trichosporon antibodies (corrected of antigen) and HLA-antigen in summer-type hypersensitivity pneumonitis in a family. Nihon Kokyuki Gakkai Zasshi 43: 741-745, 2005 (in Japanese, Abstract in English).

23. Makinodan K, Yoshikawa M, Fukuoka A, et al. A familial case of summer-type hypersensitivity pneumonitis possibly associated with bird breeder's lung diagnosed by bronchoalveolar lavage fluid. Nihon Kokyuki Gakkai Zasshi 43: 693-699, 2005 (in Japanese, Abstract in English).

24. Ono E, Maeda Y, Mori A, et al. Summer-type hypersensitivity pneumonitis-immunological examinations in onset and non-onset members. Nihon Kokyuki Gakkai Zasshi 45: 566-571, 2007 (in Japanese, Abstract in English).

25. Koike K, Sekiya M, Yae T, et al. Two cases of familial summertype hypersensitivity pneumonitis requiring differentiation from bird breeder's lung. Nihon Kokyuki Gakkai Zasshi 47: 947-952, 2009 (in Japanese, Abstract in English).

26. Hirakata $\mathrm{Y}$, Katoh T, Ishii $\mathrm{Y}$, et al. Trichosporon asahii-induced asthma in a family with Japanese summer-type hypersensitivity pneumonitis. Ann Allergy Asthma Immunol 88: 335-338, 2002.

27. Shimazu K, Ando M, Sakata T, et al. Hypersensitivity pneumonitis induced by Trichosporon cutaneum. Am Rev Respir Dis 130: 
407, 1984.

28. Ando M, Suga M, Nishiura Y, Miyajima M. Summer-type hypersensitivity pneumonitis. Intern Med 34: 707-712, 1995.

29. Warren CPW. Extrinsic allergic alveolitis: a disease commoner in non-smokers. Thorax 32: 567-569, 1977.

30. Anderson K, Morrison SM, Bourke S, et al. Effect of cigarette smoking on the specific antibody response in pigeon fanciers. Thorax 43: 798-800, 1988.

31. Arima $\mathrm{K}$, Ando $\mathrm{M}$, Ito $\mathrm{K}$, et al. Effect of cigarette smoking on prevalence of summer-type hypersensitivity pneumonitis caused by Trichosporon cutaneum. Arch Environ Health 47: 274-278, 1992.

32. Ousler MJ, Cortese C, Keeting P, et al. Modulation of transforming growth factor-beta production in normal human osteoblast-like cells by 17 beta-estradiol and parathyroid hormone. Endocrionology 129: 3313-3320, 1991.

33. Gharaee-Kermani M, Hatano K, Nozaki Y, Phan SH. Genderbased differences in bleomycin-induced pulmonary fibrosis. Am J Pathol 166: 1593-1606, 2005.

(C) 2016 The Japanese Society of Internal Medicine http://www.naika.or.jp/imonline/index.html 